\title{
Start-up of a nutrient removal system using Scenedesmus vacuolatus and Chlorella vulgaris biofilms
}

\author{
Jairo Hernán Moreno Osorio ${ }^{1 *} \mathbb{D}$, Gabriele Pinto² ${ }^{2}$ Antoninio Pollio², Luigi Frunzo ${ }^{3}$, Piet Nicolaas Luc Lens ${ }^{4,5}$ \\ and Giovanni Esposito ${ }^{6}$
}

\begin{abstract}
Microalgal biofilm-based technologies are of strong interest due to their high biomass concentrations and ability to remove nutrients from wastewater, utilize $\mathrm{CO}_{2}$ and produce secondary valuable products. This study investigated the biomass production and nutrient removal efficiency of the microalgae Scenedesmus vacuolatus ACUF_053 and Chlorella vulgaris ACUF_809 from a synthetic wastewater, describing a start-up process in a new biofilm photobioreactor (PBR) configuration. Two sets of experiments were performed. The first one compared the performance of a suspended and attached cell system under batch conditions. The second set of experiments was addressed under semi-batch conditions to study the microalgae biofilm development in the PBR. Five stages in the development of the biofilm were identified for S. vacuolatus: attachment, biofilm formation, maturation I, adaptation and maturation II. The biofilm development phases had a different nutrient removal efficiency. S. vacuolatus biofilm showed a higher phosphate demand during the first attachment and formation phases, while it had a higher nitrate demand during the subsequent phases. C. vulgaris biofilm formation was affected by the $\mathrm{pH}$ increase (up to 10.6). The biofilm PBR design using both S. vacuolatus and C. vulgaris showed potential for wastewater treatment due the higher nutrient removal rates.
\end{abstract}

Keywords: Biofilm, Microalgae, Nutrient removal, Photobioreactor, Attached cells

\section{Introduction}

In the last decades, the application of suspended microalgal technology for wastewater treatment has received considerable attention ( $\mathrm{Li}$ et al. 2010; Abdel-Raouf et al. 2012; Bernstein et al. 2014; Han et al. 2017). The main advantages of this technology rely on the simultaneous removal of pollutants and production of lipids for biodiesel (Berner et al. 2015; Bhaiji 2016) or high value renewable fine chemicals (Spolaore et al. 2006). However, microalgal culture systems have low biomass concentrations and problems with biomass/liquid separation which constitute the main drawbacks in the scale-up and industrial application of microalgal processes (Gupta et al. 2016). Microalgal biofilm systems could provide

\footnotetext{
*Correspondence: jhernanm@gmail.com

${ }^{1}$ Department of Civil and Mechanical Engineering, University of Cassino and Southern Lazio, Via Di Biasio, 43, 03043 Cassino, Italy

Full list of author information is available at the end of the article
}

an alternative approach to resolve the microalgae-based biomass production challenges. Due to the growth of the cells attached to a surface, biomass can be separated from the reactor mixed liquor without using additional electrical energy or chemicals (Johnson and Wen 2010; Ozkan et al. 2012), therefore allowing an increase in the cell retention time within bioreactors and a higher metabolic activity (Tam et al. 1994).

Biofilm photobioreactors (PBR) can be grouped into three categories: permanently submerged systems, intermittently submerged systems and perfused systems (Berner et al. 2015). The latter uses a porous substrate that supplies nutrients and moisture to the microalgae which grow on the outside of the membrane, exposed to the surrounding gas phase (Shi et al. 2007). Several works have studied the formation of microalgae biofilms growing on different substrates (Table 1). Attached algal culture systems such as the Algal Turf Scrubber (ATS) have been used successfully for growing filamentous 


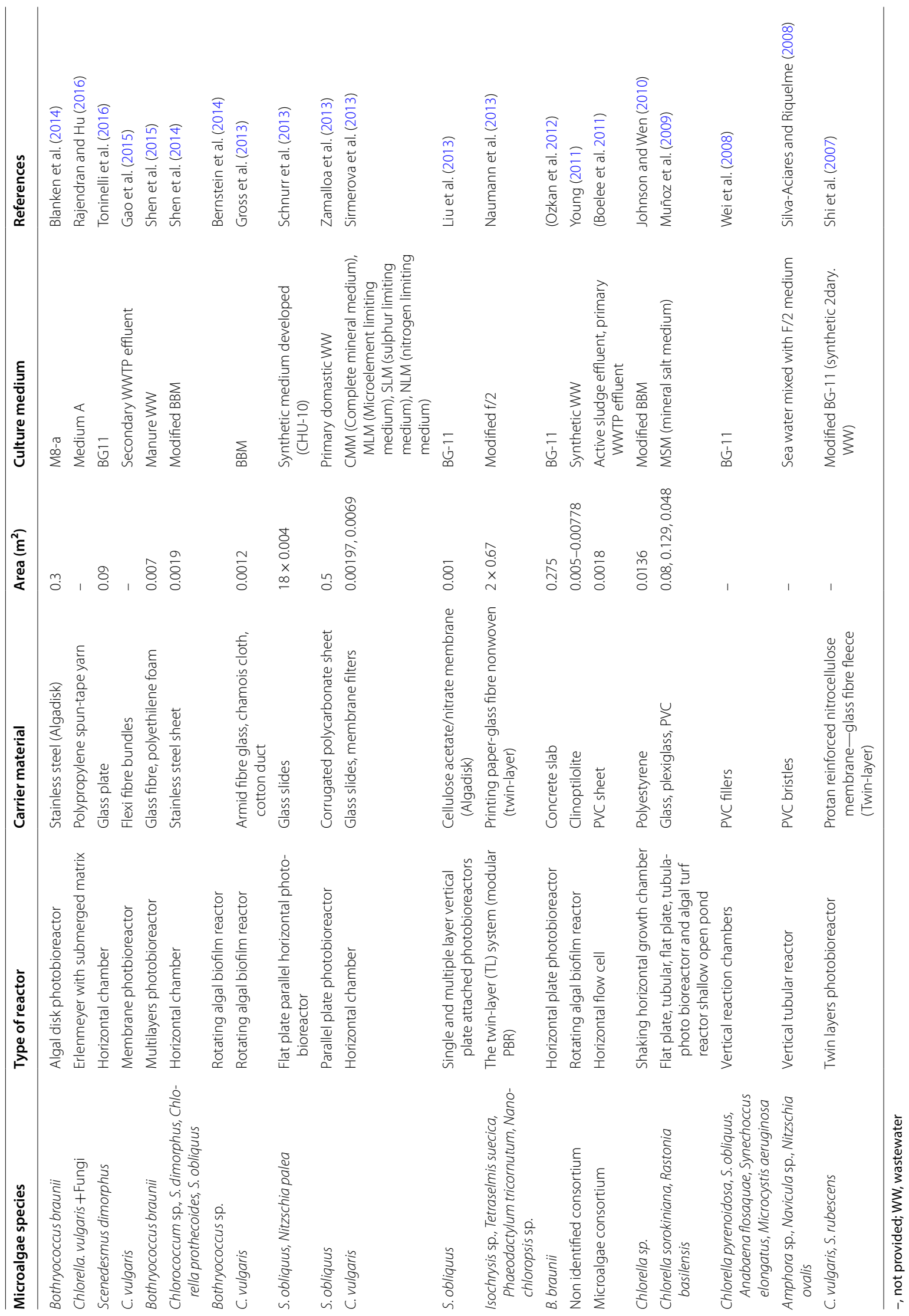


macroalgae for nutrient removal from animal wastewater (Wilkie and Mulbry 2002; Kebede-Westhead et al. 2006). Pioneering studies demonstrate the feasibility of microalgal biofilms for the removal of residual nitrogen and phosphorus from wastewater (Craggs et al. 1997; Schumacher and Sekoulov 2002; Shi et al. 2007; Babu 2011; Blanken et al. 2014). However, investigations on nutrient removal from industrial wastewater by attached microalgae are still required.

The nutrient assimilation and biomass growth in a PBR strongly depend on the photosynthetic activity (Han et al. 2017). An appropriate configuration of PBRs supports an effective photosynthesis, a higher biomass yield and an optimal removal efficiency of nitrogen and phosphorus (Prajapati et al. 2013). However, the types of PBRs that are used efficiently for algae axenic biomass cultivation do not show equal results in wastewater treatment (Han et al. 2017). Since the wastewater composition is usually highly variable, it is necessary to investigate the performance of PBRs treating different types of wastewaters and optimize the operational parameters (Muñoz et al. 2009). There are few studies concerning algal biofilm bioreactors for wastewater treatment, eventually coupled to biomass production (Katarzyna et al. 2015; Han et al. 2017).

The microalgal genera Scenedesmus and Chlorella (Chlorophyta) include a large number of species with different morphological and ultrastructural characteristics (Hegewald et al. 2013; Heeg and Wolf 2015), some of which have been reported as promising species for wastewater treatment and biomass production (Mata et al. 2010; Abdel-Raouf et al. 2012). Recent studies have demonstrated the feasibility of biofilm formation by $S$. obliquus (Liu et al. 2013; Schnurr et al. 2013; Zheng et al. 2017; Huang et al. 2018) and C. vulgaris (Gross et al. 2013; Sirmerova et al. 2013; Gao et al. 2015; Rajendran and Hu 2016; Barros et al. 2018) and their potential role for wastewater treatment. However, few works have studied the properties of S. vacuolatus for biotechnological applications, like phytoremediation of olive-mill wastewaters (La Russa 2009) or biodiesel production (Gargano et al. 2016). The aim of this work was, therefore, to evaluate the nitrogen and phosphorous removal performance of a $S$. vacuolatus and C. vulgaris biofilm grown in a PBR fed with synthetic wastewater. Two sets of experiments were performed: the first under batch conditions to compare the performance of suspended versus attached cells, and the second under semi-batch conditions to study $S$. vacuolatus and C. vulgaris biofilm development in the PBR.

\section{Materials and methods} Microalgae strains and medium

The green algae strains Scenedesmus vacuolatus ACUF_053 and Chlorella vulgaris ACUF_809 were selected in Moreno Osorio et al. (2018), according to their growth rate and nutrient removal performance. Seed cultures were maintained in BBM medium. The cultures were grown in 250-mL Erlenmeyer flasks, which contained $100 \mathrm{~mL}$ of medium and were placed on a shaking plate at $100 \mathrm{rpm}$ in an incubation room controlled at $25( \pm 2)^{\circ} \mathrm{C}$. Fluorescence light was used to maintain a constant light intensity at $95 \mu \mathrm{mol}$ photons $\mathrm{m}^{-2} \mathrm{~s}^{-1}$ (Phillips TLA, 30W/55).

The culture medium for the assays in both sections was a synthetic wastewater (modified BBM), giving an initial molar N:P ratio of 10:1 that was prepared to simulate a phosphate-rich wastewater (Moreno Osorio et al. 2018) by mixing the following solutions in distilled water: (i) nutrients and salts; (ii) $1 \mathrm{M}$ of alkaline EDTA solution; (iii) $1 \mathrm{~mL}$ of acidified iron solution; (iv) $1 \mathrm{~mL}$ of boron solution and (v) $3 \mathrm{~mL}$ of trace metals solution. The composition of each solution $\left(\mathrm{mg} \mathrm{L}^{-1}\right)$ was: (i) $\mathrm{CaCl}_{2}$ (25), $\mathrm{NaCl}$ (25), $\mathrm{NaNO}_{3}$ (250), $\mathrm{MgSO}_{4} \cdot 7 \mathrm{H}_{2} \mathrm{O}$ (75), $\mathrm{KH}_{2} \mathrm{PO}_{4}$ (175), $\mathrm{K}_{2} \mathrm{HPO}_{4}$ (175); (ii) EDTA (5) and $\mathrm{KOH}$ (3); (iii) $\mathrm{FeSO}_{4} \cdot 7 \mathrm{H}_{2} \mathrm{O}(4980)$ and $\mathrm{H}_{2} \mathrm{SO}_{4}(96 \%)\left(10 \mathrm{~mL} \mathrm{~L}^{-1}\right)$; (iv) $\mathrm{H}_{3} \mathrm{BO}_{3}$ (114.2) and (v) $\mathrm{MnCl}_{2} \cdot 2 \mathrm{H}_{2} \mathrm{O}(0.6), \mathrm{CoSO}_{4} \cdot 7 \mathrm{H}_{2} \mathrm{O}$ (0.5), $\mathrm{CuSO}_{4} \cdot 7 \mathrm{H}_{2} \mathrm{O}$ (1.6), $\mathrm{Na}_{2} \mathrm{MoO}_{4} \cdot 2 \mathrm{H}_{2} \mathrm{O}$ (0.6) and $\mathrm{ZnSO}_{4} \cdot 7 \mathrm{H}_{2} \mathrm{O}$ (8.8). The growth medium was autoclaved at $121{ }^{\circ} \mathrm{C}$ for $20 \mathrm{~min}$.

\section{Cell growth and nutrient removal assays}

Algal growth in the liquid phase was monitored by optical density (OD) in a spectrophotometer (Secomam s.250) at $680 \mathrm{~nm}$. In order to determine dry cell weight (DCW) $\left(\mathrm{mg} \mathrm{L}^{-1}\right)$, a calibration curve was employed as described by Moheimani et al. (2013). For dry weight (DW) determination, culture samples at different optical densities were measured by filtering algal samples on pre-weighed glass fibre filter paper with a pore size of $0.45 \mu \mathrm{m}$. The filters were then dried at $105^{\circ} \mathrm{C}$ in an oven for $12 \mathrm{~h}$, then algal biomass DW was determined by the difference of the two weights. $2 \mathrm{~mL}$ samples from each flask were taken daily to determine phosphorus and nitrogen concentrations after filtration $(0.45 \mu \mathrm{m})$.

\section{Evaluation of PBR system performance under batch operation}

The experimental design was divided in two sets of experiments. The performance of the nutrient removal and biofilm formation of the microalgae strains was followed under two cultivation modes as: set 1.1 compared attached and suspended growth and set 1.2 the nutrient removal efficiency in semi-batch mode of $S$. vacuolatus. The set 2.1 compared attached and suspended growth and the set 2.2 the algal biofilm formation and nutrient removal efficiency in semi-batch mode of $C$. vulgaris. The 
first set consisted of a batch period of 7 days where the attached growth in the PBR was tested and compared to the suspended growth. In the second set, the biofilm PBR was operated in semi-batch mode for 41 days. Different nutrient concentrations were tested in order to analyse the performance of the biofilm system (Table 2). Daily changes in biofilm morphology of both microalgae strains were recorded by digital photography.

\section{Suspended cell culture}

For microalgal suspended cultures, the cells were grown in triplicate in $100 \mathrm{~mL}$ medium inside $250 \mathrm{~mL}$ Erlenmeyer flasks and incubated at $25( \pm 3)^{\circ} \mathrm{C}$ with horizontal shaking at $100 \mathrm{rpm}$ supplied with constant illumination $\left(90 \mu \mathrm{mol} \mathrm{m}^{-2} \mathrm{~s}^{-1}\right)$ by a cold-white directional LED light source (Beghelli cold white lamps, $12 \mathrm{~W}$ ).

\section{Attached cell culture in pilot PBR}

The PBR design was a stationary biofilm reactor design (Fig. 1). The system is a vertical bioreactor made of plexiglass with the dimensions of $0.145 \times 0.10 \times 0.185 \mathrm{~m}$ (wide, long, height). In these reactors, the biofilm develops on the flat surface of the PBR (Fig. 1a) and a thin layer of liquid is flown over it, recycled by a pump (Gross et al. 2015). Cotton fabric was tested as supporting material for algae attachment. This carrier was selected because of the promising results obtained in previous biofilm attachment assays (Carbone et al. 2017). Moreover, as reported in previous studies, this material presents other advantages such as local availability, low cost, reusable and easy production (Johnson and Wen 2010).

The PBR design facilitated the establishment and growth of the microalgal biofilm. The vertical position of the carrier allowed its homogeneous illumination and flow of the synthetic wastewater over the biofilm. The synthetic wastewater circulates in the system from the reservoir bottle through plastic pipes to the PBR where the flow was split in 4 dropper devices. The medium flows as a thin layer on the carrier and then falls to the bottom of the reactor where it is collected in a sink that directs the medium to the output valve. From the outlet, the medium runs through a plastic pipe back to the reservoir bottle (Fig. 1a).

Table 2 Initial nitrogen and phosphorus concentrations used in the experiment of this study on S. vacuolatus and $C$. vulgaris biofilm performance

\begin{tabular}{|c|c|c|c|c|c|c|}
\hline & \multicolumn{4}{|c|}{ S. vacuolatus ACUF_053 } & \multicolumn{2}{|c|}{ C. vulgaris ACUF_809 } \\
\hline & \multirow{3}{*}{$\begin{array}{l}\text { Set } 1.1 \\
\text { Batch } \\
\text { Dose }\end{array}$} & \multicolumn{3}{|l|}{ Set 1.2} & \multirow{3}{*}{$\begin{array}{l}\text { Set } 2.1 \\
\text { Batch } \\
\text { Dose }\end{array}$} & \multirow{3}{*}{$\begin{array}{l}\text { Set } 2.2 \\
\text { Semibatch } \\
\text { Initial dose }\end{array}$} \\
\hline & & \multicolumn{3}{|l|}{ Semibatch } & & \\
\hline & & Initial dose & 2nd dose & Final dose & & \\
\hline $\mathrm{NO}_{3}{ }^{-}-\mathrm{N}\left(\mathrm{mg} \mathrm{L}^{-1}\right)$ & 14 & 14 & 20 & 54 & 14 & 14 \\
\hline $\mathrm{PO}_{4}{ }^{3-}-\mathrm{P}\left(\mathrm{mg} \mathrm{L}^{-1}\right)$ & 3.5 & 6.5 & 13 & 13 & 6.5 & 6.5 \\
\hline Time (days) & 7 & 7 & 10 & 24 & 4 & 41 \\
\hline
\end{tabular}

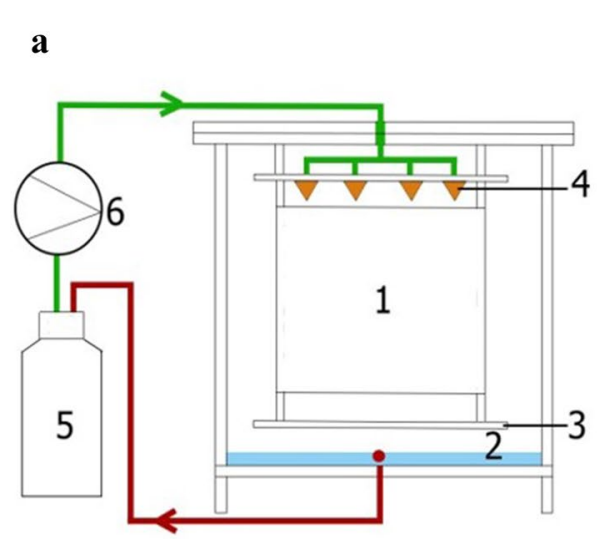

b

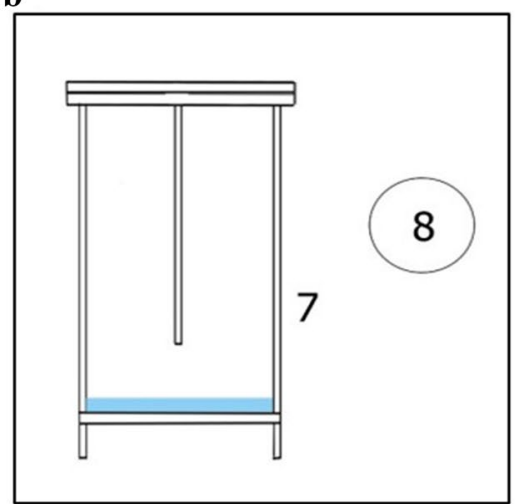

C

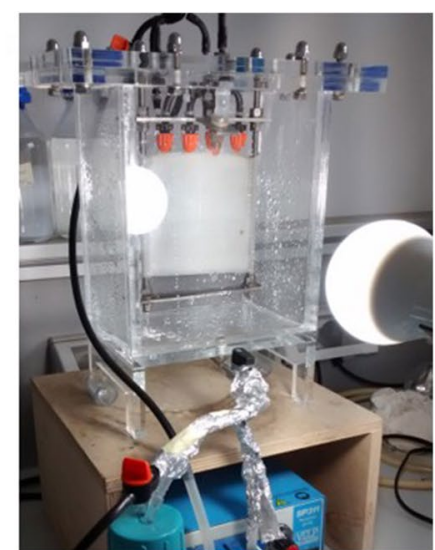

Fig. 1 Biofilm PBR design: a PBR front view, b PBR side view and c PBR photograph. (1) Cotton carrier (for attachment of microalgae), (2) synthetic wastewater, (3) carrier holder, (4) dropper, (5) reservoir of synthetic growth medium, (6) pump, (7) PBR side view and (8) LED lamp 
The support material was cut into $0.10 \times 0.10 \mathrm{~m}$ pieces and positioned on the carrier holder in the centre of the chamber (Fig. 1). The system was operated in semi-batch mode and at room temperature $\left(25 \pm 3{ }^{\circ} \mathrm{C}\right)$. The PBR was incubated with $100 \mathrm{~mL}$ of a microalgae suspension precultivated in a shake flask with a cotton plug to a container (200 mL Pirex bottle covered with aluminium foil) with the synthetic wastewater. The algal cell suspension had an $\mathrm{OD}_{680}$ of 0.2 and 0.25 for $S$. vacuolatus and C. vulgaris, respectively, for a concentration of $\approx 3.5 \times 10^{7}$ cells $\mathrm{mL}^{-1}$. The medium was injected at a flow rate of $4.45 \mathrm{~mL} \mathrm{~min}^{-1}$ without air insufflation.

For the entire duration of the experiments, the light intensity was set at $5920 \mathrm{lux}\left(90 \mu \mathrm{mol} \mathrm{m} \mathrm{m}^{-2} \mathrm{~s}^{-1}\right)$. Only one side of the carrier was illuminated by a cold-white directional LED light source (Beghelli cold white lamps, $12 \mathrm{~W}$ ) (Fig. 1b). Cool white LED lights have a wider-spectrum wavelength (380-760 nm) which encompasses the blue, red and green light spectrum (Yan et al. 2013). Since the PBR was transparent, aluminium foil was used to cover the bottom of the reactor $(4 \mathrm{~cm})$ and only the upper portion of the reactor was illuminated. This selective pressure allowed minimizing the suspended microalgae growth in the medium.

\section{Evaluation of PBR system performance under semi-batch operation}

The operation of the PBR was continued after the conclusion of the comparative periods as described above. The reactor was fed with new medium after the complete removal of one or both nutrients (phosphate and nitrate). Three increasing $\mathrm{NO}_{3}{ }^{-}-\mathrm{N}$ and $\mathrm{PO}_{4}{ }^{3-}-\mathrm{P}$ concentrations were tested with $S$. vacuolatus ACUF_053 according to the consumption of these nutrients over time (Table 2). On other hand, only one concentration was tested for C. vulgaris ACUF_053 in the synthetic wastewater with $\mathrm{NO}_{3}{ }^{-}$ as nitrogen source due to the different nutrient removal trends observed. Algal biomass was not harvested to avoid external contamination of the biofilm system.

\section{Analytical methods}

Medium samples from the synthetic wastewater reservoir were collected daily in triplicate for absorbance, $\mathrm{pH}$, $\mathrm{NO}_{3}{ }^{-}$and $\mathrm{PO}_{4}{ }^{3-}$ analysis. The $\mathrm{pH}$ values were measured with a $\mathrm{pH}$ meter Bench model AD-1030 (Adwa Instruments Inc., Szeged, Hungary). Phosphorus was measured as orthophosphate $\left(\mathrm{PO}_{4}{ }^{3-}-\mathrm{P}\right)$ and nitrogen as nitrate $\left(\mathrm{NO}_{3}{ }^{-}-\mathrm{N}\right)$. Analyses of nitrate and phosphate were performed by ion chromatography using a 761 compact IC analyzer (Metrohm, Herisau, Switzerland) as described by APHA (2005).
The nutrient removal efficiency $\operatorname{Re}(\%)$ was calculated with the equation $\operatorname{Re}=\left(\Delta S \cdot S_{i}^{-1}\right) * 100$, where Re represents the nutrient removal efficiency of the substrate $\left(\mathrm{NO}_{3}{ }^{-}-\mathrm{N}\right.$ or $\left.\mathrm{PO}_{4}{ }^{3-}-\mathrm{P}\right), \Delta \mathrm{S}$ is the variation of nutrient concentration $\left(\mathrm{mg} \mathrm{L}^{-1}\right)$ and $S_{\mathrm{i}}$ is the initial concentration of the nutrient. Mean and standard deviation were calculated. One way ANOVA for statistical examination of significant differences in the nutrient removal efficiency between and within suspended and attached cultures was carried out using OriginPro 2017 (OriginLab, Northampton, MA) with a confidence level of $95 \%$. The null hypothesis stated that the removal efficiencies were equal.

\section{Results}

\section{S. vacuolatus ACUF_053 performance}

Evaluation of PBR system performance under batch operation

Suspended and attached S. vacuolatus ACUF_053 cells cultivated under the same conditions in synthetic wastewater as described above were able to grow in both culture conditions. The absorbance measurements showed that the biomass growth in the suspension was linear with a short lag phase and no stationary phase was reached (Fig. 2a). No biomass growth was observed in the medium of the PBR system, suggesting that cells grew exclusively on the carrier material (Fig. 2a).

During the first 3 days, $\mathrm{pH}$ values of the cell culture in suspension increased reaching an alkaline $\mathrm{pH}$ of 10 (Fig. 2b). On day seven, a drop of the $\mathrm{pH}$ of the medium was observed. In the PBR system, the $\mathrm{pH}$ of the medium dropped to 7.27 at day seven, when complete removal of nitrate and phosphate was observed in the medium. Then the reactor was fed with a new phosphorus solution with the double phosphorus concentration $(6.5 \mathrm{mg}$ $\left.\mathrm{PO}_{4}{ }^{3-}-\mathrm{P} \mathrm{L}^{-1}\right)$.

In the suspended culture system, complete $\mathrm{PO}_{4}{ }^{3-}-\mathrm{P}$ removal was obtained after 4 days, while the complete depletion of nitrogen (13.5 $\mathrm{mg} \mathrm{NO}_{3}{ }^{-}-\mathrm{N} \mathrm{L}^{-1}$ ) required 6 days (Fig. 2c, d). Different behaviour was observed in the algal biofilm system, a complete phosphorus removal ( $4 \mathrm{mg} \mathrm{PO}_{4}{ }^{3-}-\mathrm{P} \mathrm{L}^{-1}$ ) was achieved from the first day of the experiment (Fig. 2c), although no significant difference was observed between the phosphorus removal efficiency of the suspended and attached systems $(P>0.05)$. Due to the fast and complete phosphate depletion, the nitrate removal ceased. Indeed, $28 \%$ of the nitrate concentration was consumed the first day in the PBR and no uptake was observed for the subsequent 2 days. At day three, the system was fed with phosphate only $\left(10 \mathrm{mg} \mathrm{PO}_{4}{ }^{3-} \mathrm{L}^{-1}\right.$ or $3.2 \mathrm{mg} \mathrm{PO}_{4}{ }^{3-}-\mathrm{P} \mathrm{L}^{-1}$ ), after which the $\mathrm{NO}_{3}{ }^{-}-\mathrm{N}$ removal started again until its complete removal. 

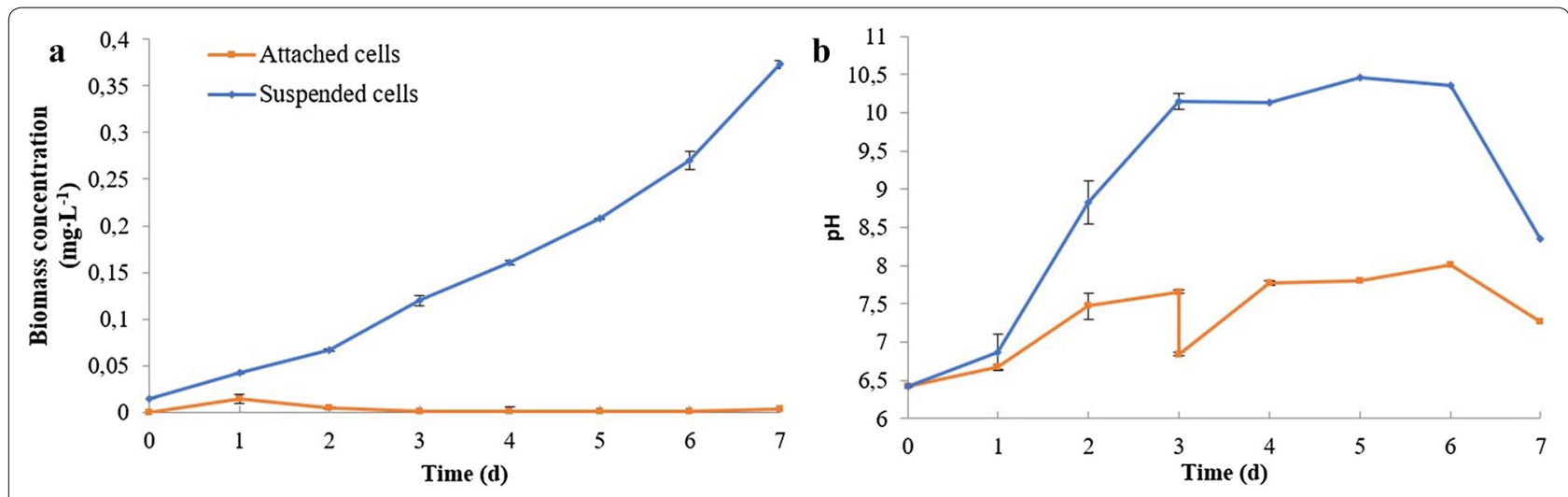

c

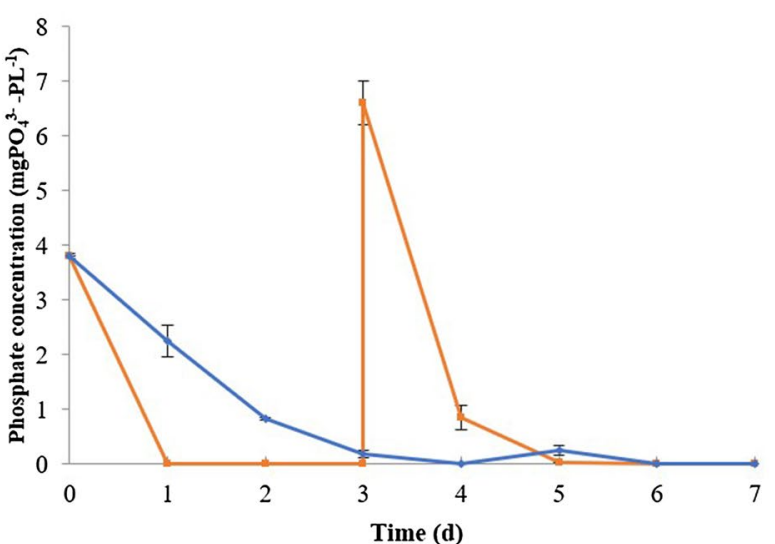

d

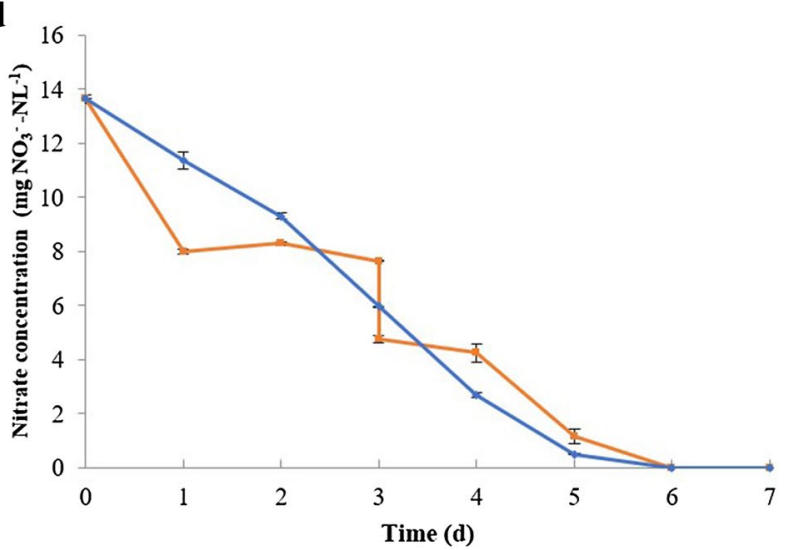

Fig. 2 a Biomass growth, $\mathbf{b}$ pH changes in liquid, $\mathbf{c}$ phosphorus and $\mathbf{d}$ nitrogen removal kinetics of S. vacuolatus ACUF_053 cultivated in suspension and as attached biofilm in PBR. The error bars correspond to the standard deviation

Nitrogen $\left(\mathrm{NO}_{3}{ }^{-}-\mathrm{N}\right)$ removal was constant and regular in the suspended cell cultures until its complete starvation on day $6.28 \%$ of the nitrate concentration was consumed the first day in the PBR and no uptake was observed until day three, when the system was re-fed phosphorus $\left(3.2 \mathrm{mg} \mathrm{PO}_{4}{ }^{3-}-\mathrm{P} \cdot \mathrm{L}^{-1}\right)$. Complete $\mathrm{NO}_{3}{ }^{-}-\mathrm{N}$ removal in the suspended cell culture and PBR was obtained on the 6th day of the assay (Fig. 2d). No significant difference was observed between the nitrogen removal efficiency of the suspended and attached systems $(P>0.05)$. No biomass growth was observed in the synthetic wastewater in the PBR system, confirming that the growth was exclusively on the fabric carrier. After 7 days of the batch comparative assay, semi-batch conditions were applied to the PBR system.

\section{Evaluation of PBR system performance under semi-batch operation}

Scenedesmus vacuolatus ACUF_053 biofilm formation was tested under semi-batch conditions for 41 days in a new PBR. The PBR was fed with new synthetic wastewater when $\mathrm{NO}_{3}{ }^{-}-\mathrm{N}$ depletion was achieved. Figure 3 shows the daily changes in the biofilm morphology.

Five phases were identified in the development of the biofilm from the morphological changes observed: (1) attachment of the microalgae cells inoculated in the medium onto the carrier; (2) biofilm formation, the attached cells grew on the carrier and cover its full area; (3) maturation I, microalgae biomass on the carrier became ticker; (4) adaptation; microalgae biomass partially detached from the carrier and (5) maturation II, microalgae biomass on the carrier increased in thickness.

After the initial biofilm maturation phase, the biofilm showed a detachment period that was monitored, reason why the biofilm biomass was not harvested. After this maturation I and detachment phase, the biofilm could regrow in 10 days from the biomass that remained on the carrier surface (adaptation phase); comparable to the time required for the biofilm initial attachment phase (Fig. 3).

The $\mathrm{NO}_{3}{ }^{-}$-N contained in the medium was efficiently consumed by the microalgal biofilm, as shown by its concentration in the synthetic wastewater (Fig. 4a). It should be noted that the five periods show some differences 


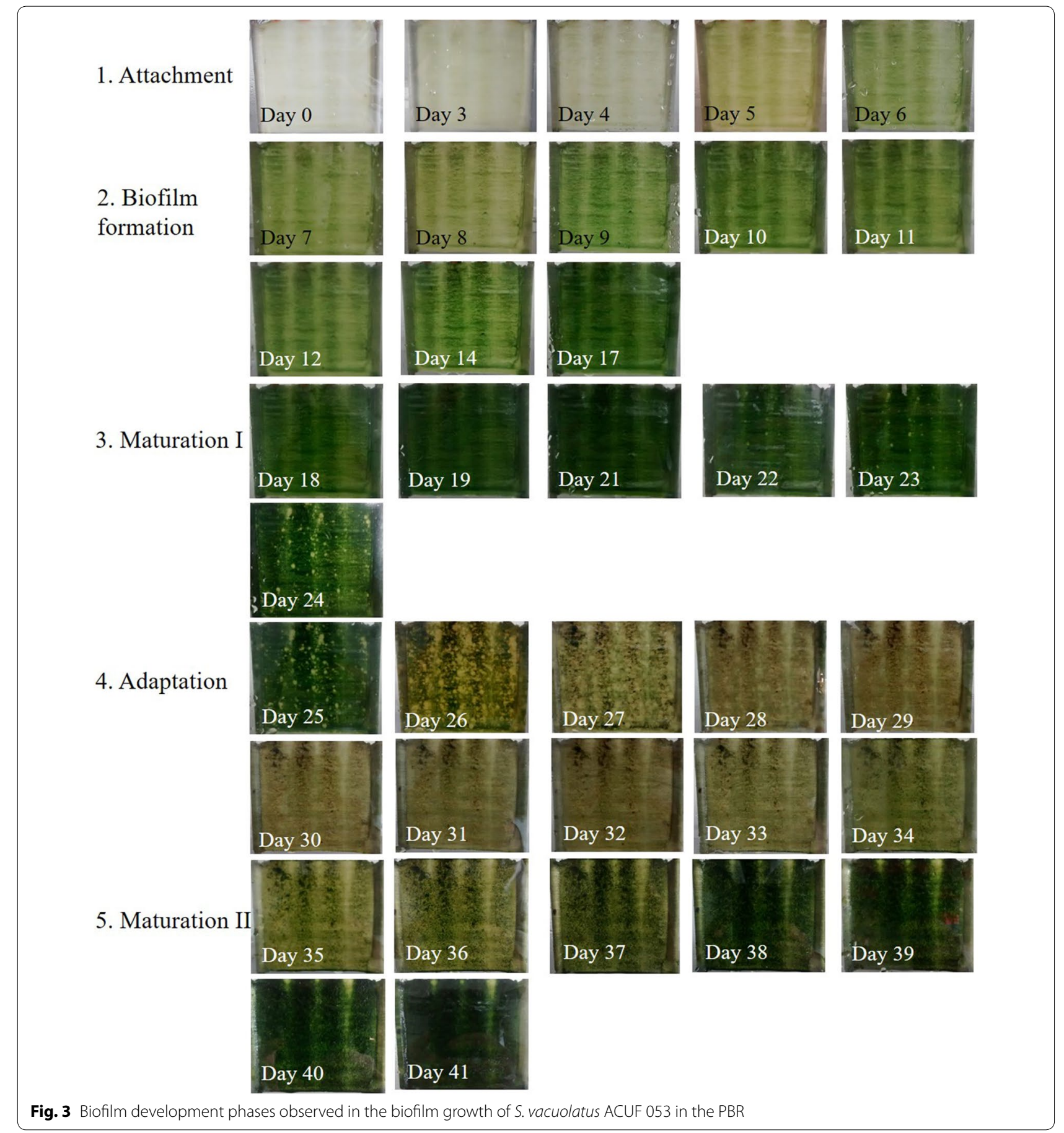

in nitrate removal rates. As expected, the lower rate occurs during the biofilm formation in phase 1. During phases 2 and 3, it is possible to see similar removal rates despite the change in nitrogen concentration (from 27 to $54 \mathrm{mg} \mathrm{NO}_{3}{ }^{-}-\mathrm{N} \mathrm{L}^{-1}$ ) in the PBR influent. During phase 4 the rate of the nitrate removal decreased, but a higher $\mathrm{NO}_{3}{ }^{-}-\mathrm{N}$ removal rate was detected in the last period.
By analysing the $\mathrm{PO}_{4}{ }^{3-}-\mathrm{P}$ concentration in the system influent (Fig. 4a), the phosphorus removal rate was high during the attachment phase and the second biofilm maturation phase, with removal efficiencies of $72.9 \%$ and $57.8 \%$, respectively, after 1 day of refreshing the medium. However, in the second maturation phase the system did not reach a complete phosphorus removal 


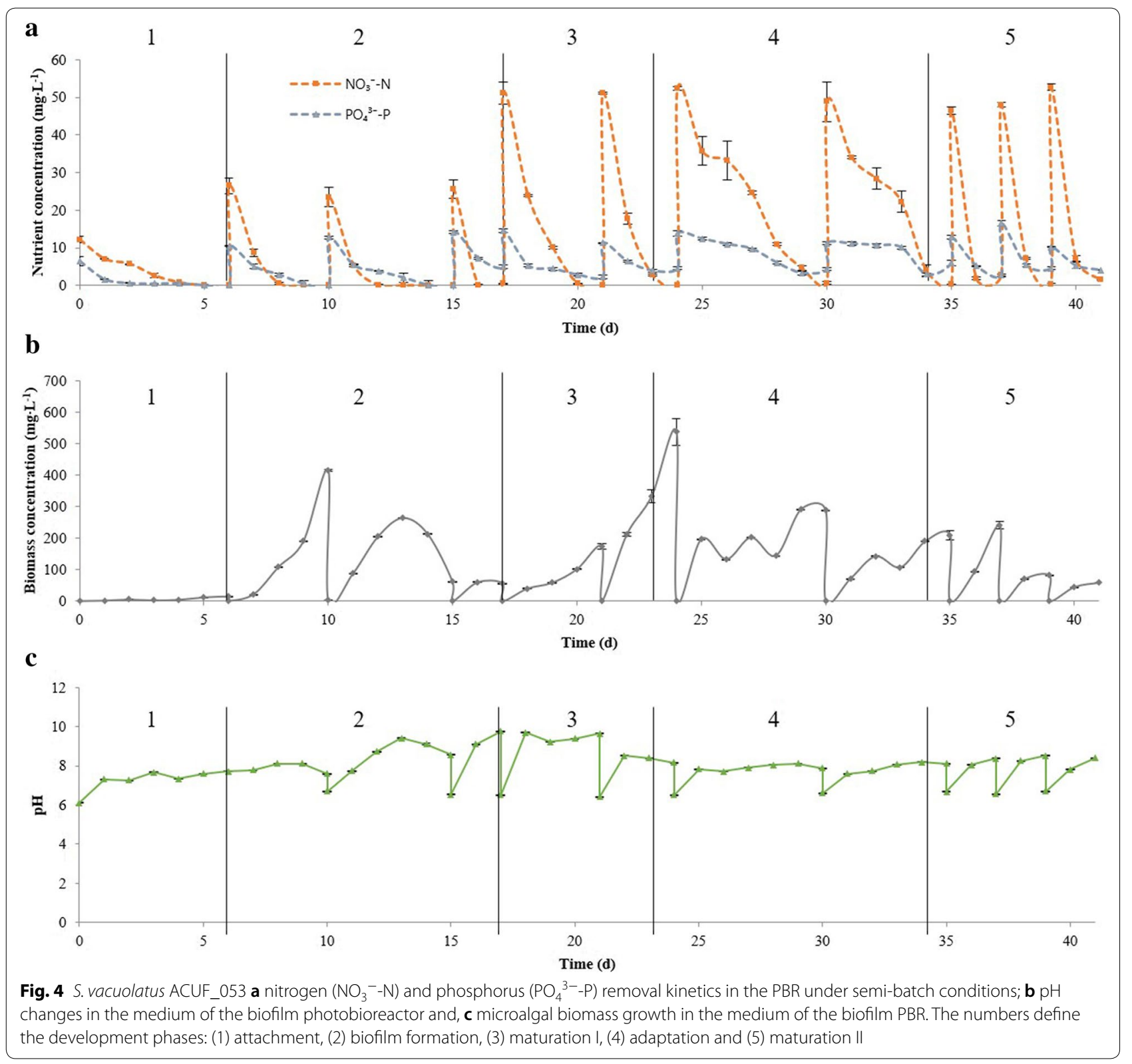

before nitrogen limitation occurred in the medium. After the attachment phase, the phosphorous demand decreased inversely to the nitrogen demand, as shown by the faster $\mathrm{NO}_{3}{ }^{-} \mathrm{-N}$ consumption. For this reason, the system was fed with new synthetic wastewater when complete $\mathrm{NO}_{3}{ }^{-}-\mathrm{N}$ removal was recorded, although $2.5-3 \mathrm{mg}$ $\mathrm{PO}_{4}{ }^{3-}$ - $\mathrm{P} \mathrm{L}$ was still present in the medium.

The synthetic wastewater in the PBR showed low variations in the $\mathrm{pH}$ (7.3-8.1) from the beginning until day ten. Higher $\mathrm{pH}$ values (9.7) were recorded between days 13 and 21 of the experiment, during the maturation I period, after the increase of $\mathrm{NO}_{3}{ }^{-}-\mathrm{N}$ and $\mathrm{PO}_{4}{ }^{3-}-\mathrm{P}$ doses from $13.5 \mathrm{mg} \mathrm{NO}_{3}{ }^{-}-\mathrm{N} \mathrm{L}^{-1}$ and $6.5 \mathrm{mg} \mathrm{PO}_{4}{ }^{3-}-\mathrm{P} \mathrm{L}^{-1}$ to
$27 \mathrm{mg} \mathrm{NO}_{3}{ }^{-}-\mathrm{N} \mathrm{L}^{-1}$ and $13 \mathrm{mg} \mathrm{PO}_{4}{ }^{3-}-\mathrm{P} \mathrm{L}^{-1}$, respectively. Consequently, the concentrations were further increased to $54 \mathrm{mg} \mathrm{L}^{-1}$ of $\mathrm{NO}_{3}{ }^{-}-\mathrm{N}$ and $13 \mathrm{mg} \mathrm{L}^{-1}$ of $\mathrm{NO}_{3}{ }^{-}-\mathrm{N}$ after day 21 , but the system reached a $\mathrm{pH}$ stability similar to that observed during the first 10 days. The maximum $\mathrm{pH}$ value during the adaptation and maturation II phases was 8.5 (Fig. 4b).

The algal biomass concentration in the reactor medium was measured daily (Fig. 4c). During the initial 6 days, no or a very low biomass concentration $\left(0.012 \mathrm{mg} \mathrm{L}^{-1}\right.$, day 6) was detected. After day 7, the beginning of an exponential growth was observed when the PBR was fed for the second time with synthetic wastewater with $13.5 \mathrm{mg}$ 
$\mathrm{NO}_{3}{ }^{-}-\mathrm{N}^{-} \mathrm{L}^{-1}$ and $6.5 \mathrm{mg} \mathrm{PO}_{4}{ }^{3-}-\mathrm{P} \mathrm{L}^{-1}$. At day ten, a biomass concentration of $0.42 \mathrm{mg} \mathrm{L}^{-1}$ was measured in the medium and the reactor was fed with $27 \mathrm{mg} \mathrm{NO}_{3}{ }^{-}-\mathrm{N} \mathrm{L}^{-1}$ and $13 \mathrm{mg} \mathrm{PO}_{4}{ }^{3-}-\mathrm{P} \mathrm{L}^{-1}$. Between day 10 and 13, a linear increase of the biomass in the medium was observed and $0.26 \mathrm{mg} \mathrm{L}^{-1}$ was achieved. On day 17 of the PBR run, the reactor was fed with $54 \mathrm{mg} \mathrm{NO}_{3}{ }^{-}-\mathrm{N} \mathrm{L}^{-1}$ and $13 \mathrm{mg}$ $\mathrm{PO}_{4}{ }^{3-}-\mathrm{P} \mathrm{L}^{-1}$ and a new exponential biomass growth phase was observed in the recirculation medium. This rise was recorded until the 21th day, when the biomass concentration was $0.17 \mathrm{mg} \mathrm{L}^{-1}$ and the PBR was fed with the same nutrient concentrations (end of formation phase).

Higher biomass concentrations in the medium $\left(0.53 \mathrm{mg} \mathrm{L}^{-1}\right)$ were observed on day 24 of the experiment, 3 days after the exponential biomass increase (Fig. 4c). This higher value is probably due to biofilm detachment. From day 25, an adaptation phase was observed and the biomass concentration in the medium decreased although the values recorded in this phase $\left(0.28 \mathrm{mg} \mathrm{L}^{-1}\right)$ were still higher than in the attachment phase, probably due to the detachment of death cells from the biofilm. The second maturation phase began on day 35 when the start of a gradual increase in the biofilm biomass concentration was observed (Fig. 4c).

\section{C. vulgaris ACUF_809 performance Evaluation of PBR system performance under batch operation}

Chlorella vulgaris ACUF_809 was able to grow in both culture conditions. No lag phase was observed during biomass growth in the suspension assay and a decrease was evident from day 3 to 6 (Fig. 5a). On the other hand, a low biomass concentration was observed in the medium of the PBR system, suggesting that-like for $S$. vacuolatus ACUF_053-the cells grew mainly on the carrier material (Fig. 5a).

A steep increase of the $\mathrm{pH}$ values was observed in both suspended and attached cultivations during the first day, reaching an alkaline $\mathrm{pH}$ of 9.4 and 9.9, respectively (Fig. 5b). A slightly increased $\mathrm{pH}$ in the suspended cultivation was observed until day 3 and kept constant till the end of the experiment. The $\mathrm{pH}$ of the PBR medium dropped to 6.8 at day two, when the reactor was fed with a new phosphate dose $\left(6.5 \mathrm{mg} \mathrm{PO}_{4}{ }^{3-}-\mathrm{P} \mathrm{L}^{-1}\right)$. In the suspended culture system, complete $\mathrm{PO}_{4}{ }^{3-}-\mathrm{P}$ and $\mathrm{NO}_{3}{ }^{-}-\mathrm{N}$ removal was obtained after 3 days (Fig. 5c, d). However, in the algal biofilm system almost complete phosphorus removal $\left(6.5 \mathrm{mg} \mathrm{PO}_{4}{ }^{3-}-\mathrm{P} \mathrm{L}^{-1}\right)$ was achieved at day two (Fig. 5c). A significant difference was observed between
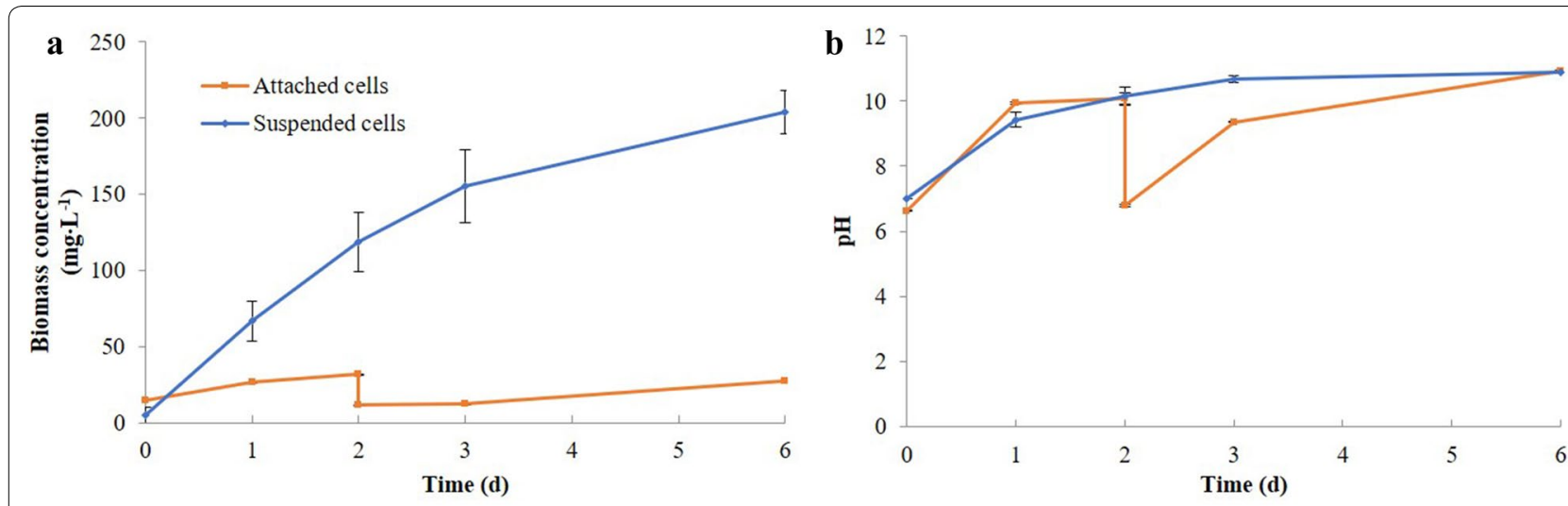

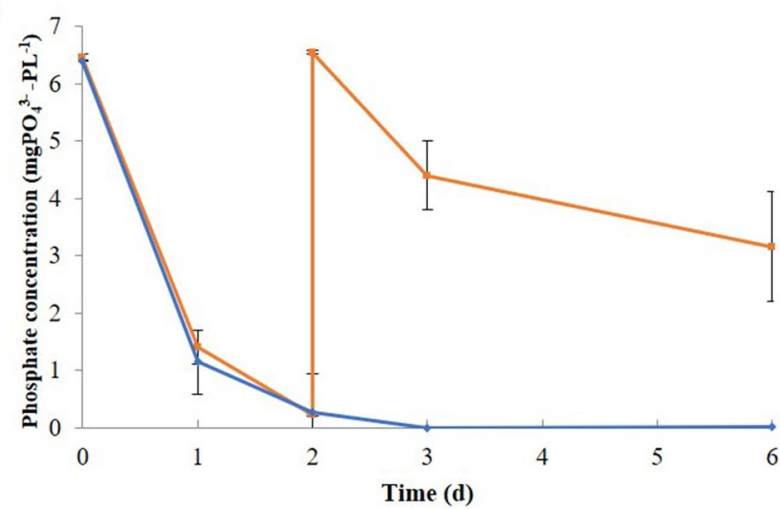

\section{d}

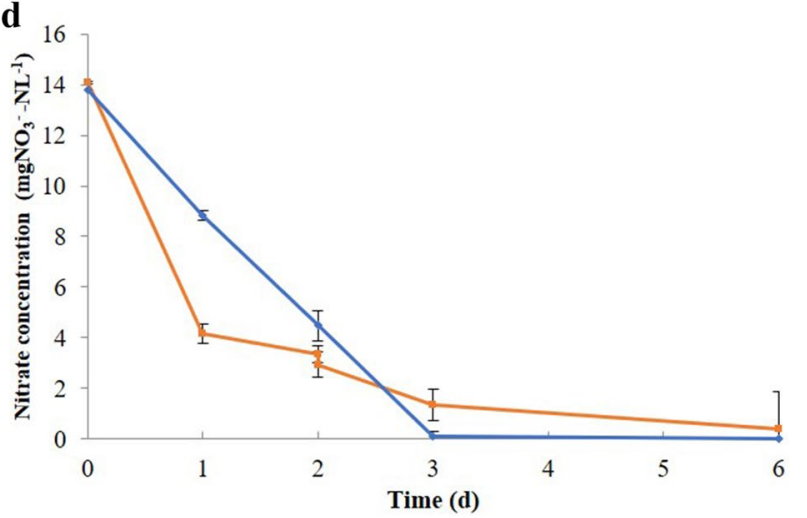

Fig. 5 a Biomass growth, $\mathbf{b}$ pH changes in liquid medium, c phosphorus and $\mathbf{d}$ nitrogen removal kinetics of C. vulgaris ACUF_809 cultivated in suspension and as attached biofilm in the PBR. The error bars correspond to the standard deviation 

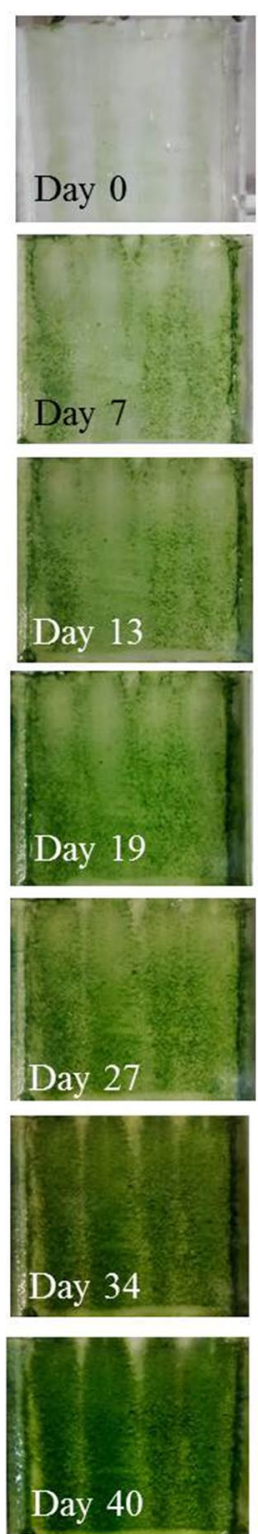
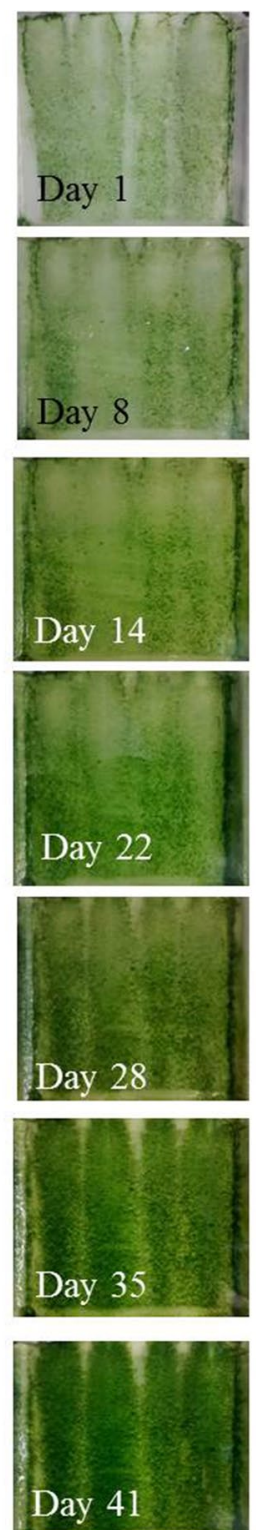
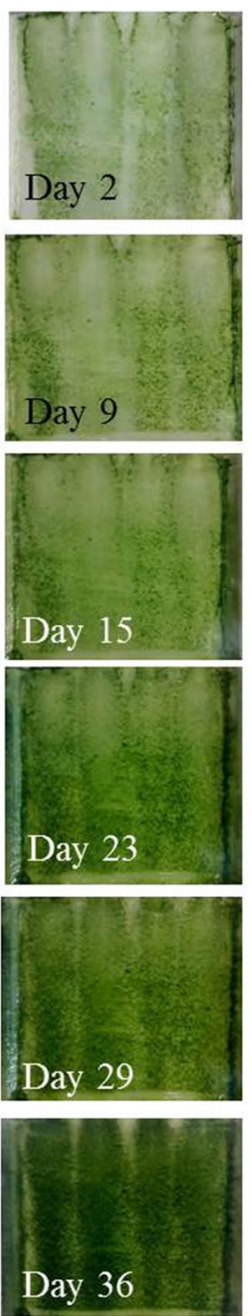
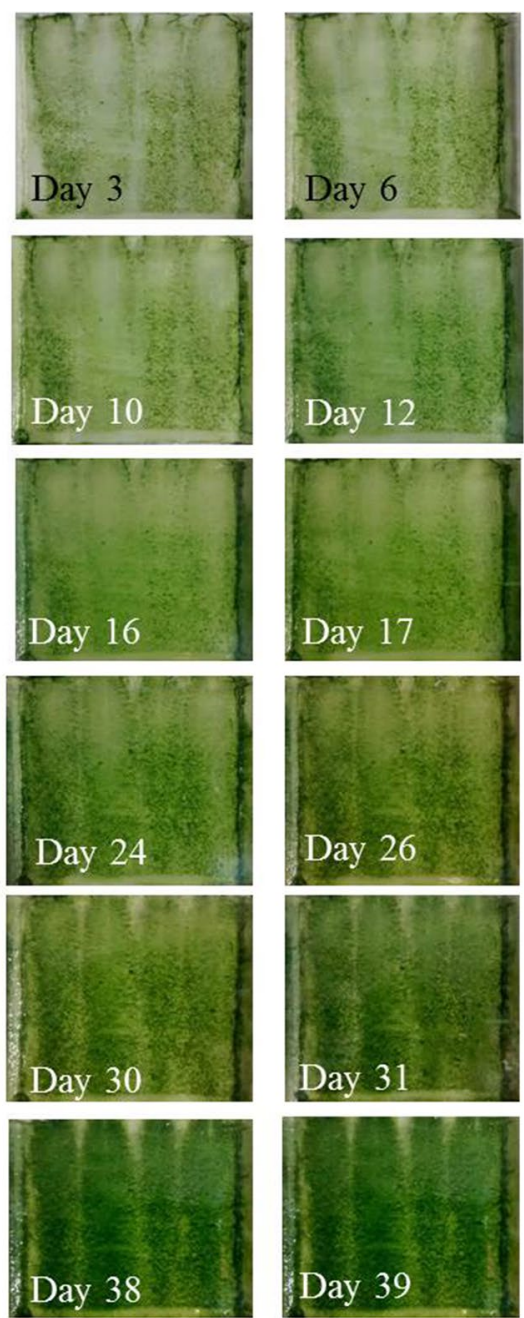

Fig. 6 Photographic record of C. vulgaris ACUF 809 biofilm development on cotton fabric in the PBR

the phosphorus removal efficiency of the suspended and attached systems $(P<0.05)$. The nitrate removal rate decreased between day one and two, it increased again after day two. When almost complete $\mathrm{NO}_{3}{ }^{-}-\mathrm{N}$ and $\mathrm{PO}_{4}{ }^{3-}$ - $\mathrm{P}$ removal was observed in the medium, then the reactor was fed with a new phosphorus solution with equal initial dose $\left(6.5 \mathrm{mg} \mathrm{PO}_{4}{ }^{3-}-\mathrm{P} \mathrm{L}^{-1}\right)$.

A lower $\mathrm{NO}_{3}{ }^{-}-\mathrm{N}$ removal efficiency was observed during the first day of cultivation in the suspended cell cultures. However, a steep decrease was recorded from day one to three, until its complete depletion. A significant difference was observed between the nitrogen removal efficiency of the suspended and attached systems
$(P<0.05)$. After 6 days of batch comparative assay, semibatch conditions were applied to the PBR system.

\section{Evaluation of $P B R$ system performance under semi-batch operation}

Chlorella vulgaris ACUF_809 biofilm formation was followed under semi-batch conditions for 41 days in the same PBR configuration system. The PBR was fed with synthetic wastewater with a higher concentration of nitrogen $\left(13.5 \mathrm{mg} \mathrm{NO}_{3}{ }^{-}-\mathrm{N} \mathrm{L}^{-1}\right)$ and phosphorus $(6.5 \mathrm{mg}$ $\left.\mathrm{PO}_{4}{ }^{3-}-\mathrm{P} \mathrm{L}^{-1}\right)$, and reloaded with new synthetic wastewater whenever the complete removal of both or one of the nutrients was achieved. Figure 6 shows the daily changes 


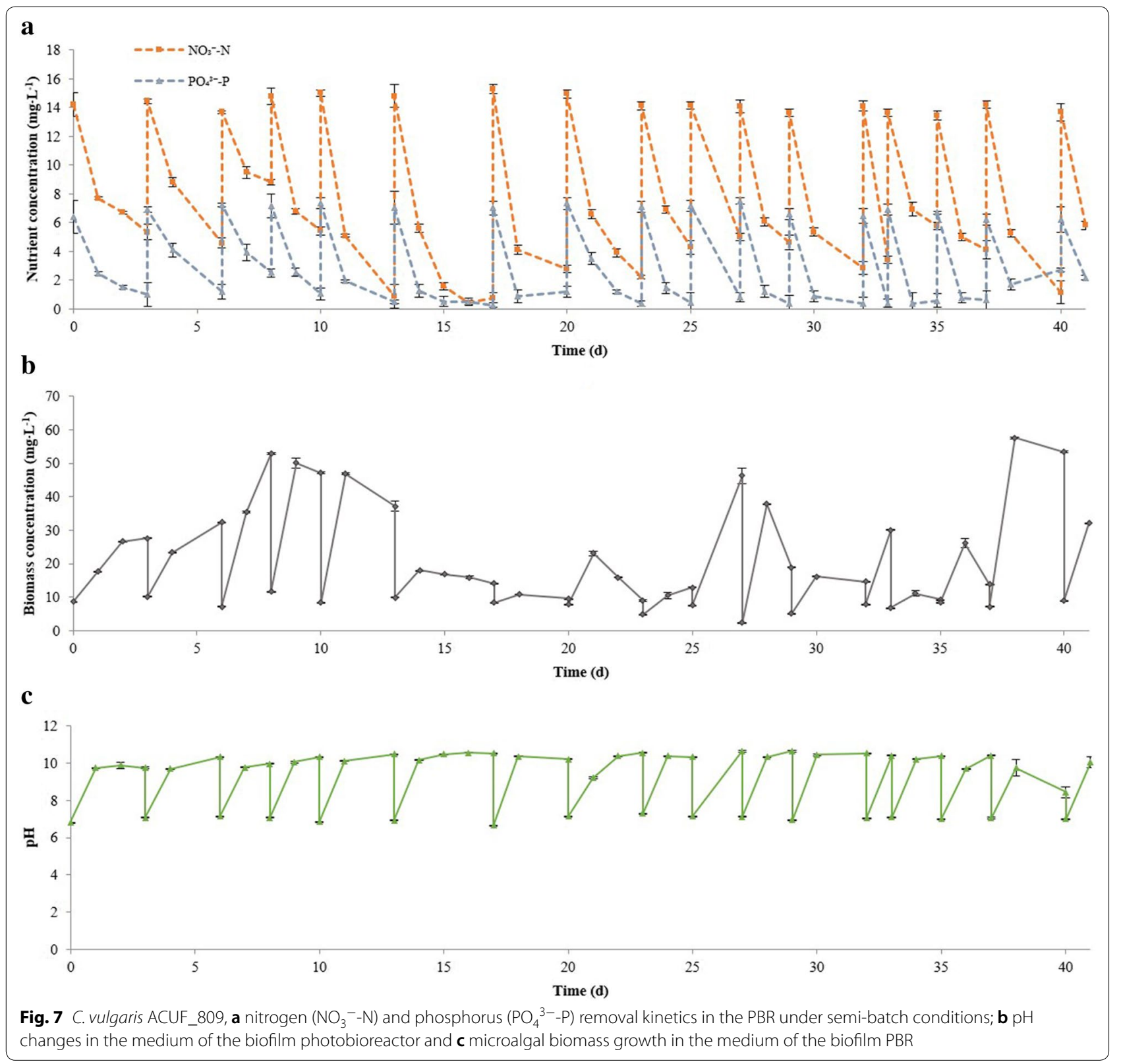

in the biofilm morphology. A gradual but constant development of the biofilm was observed along the 41 days of the experiment. No abrupt morphological changes were observed in the biofilm formation and no association with the nutrient consumption could be inferred.

The $\mathrm{NO}_{3}{ }^{-}-\mathrm{N}$ and $\mathrm{PO}_{4}{ }^{3-}-\mathrm{P}$ contained in the medium were efficiently consumed by the microalgae biofilm, as shown by the concentration in the synthetic wastewater (Fig. 7a). Interestingly, removal of phosphorus and nitrogen was mainly constant during the cultivation time. A low removal efficiency of both nutrients was observed from day 6 to 10 , followed by a higher nutrient removal efficiency after 1 day of feeding with new medium, i.e. $62-73 \%$ of $\mathrm{NO}_{3}{ }^{-}-\mathrm{N}$ during the period from day 10 to 21 and $80.5-85.7 \%$ of $\mathrm{PO}_{4}{ }^{3-}-\mathrm{P}$ from day 14 to day 18 . The synthetic wastewater in the PBR showed a fast increase of the $\mathrm{pH}$ during the first day after each medium renewal, i.e. $7( \pm 0.4)$ to 10.2 $( \pm 0.2)$ along the experiment. Higher $\mathrm{pH}$ values $(10.6)$ were recorded at days 17 of the experiment (Fig. 7b).

The algal biomass concentration in the reactor medium was measured daily (Fig. $7 \mathrm{c}$ ). A low, but constant biomass concentration $\left(8.2-57 \mathrm{mg} \mathrm{L}^{-1}\right)$ was recorded during the 41 days of the experiment. Five peaks of biomass concentration were measured on days $8\left(52.8 \mathrm{mg} \mathrm{L}^{-1}\right)$, 9 (50.1 $\left.\mathrm{mg} \mathrm{L}^{-1}\right), 11\left(46.8 \mathrm{mg} \mathrm{L}^{-1}\right), 27\left(46.2 \mathrm{mg} \mathrm{L}^{-1}\right)$ and $38\left(57.6 \mathrm{mg} \mathrm{L}^{-1}\right)$. On the contrary, two periods of low 
biomass concentration were observed from day 13 to 25 (12.9-23 mg L $\left.\mathrm{mg}^{-1}\right)$ and from day 30 to $35\left(9.3-30 \mathrm{mg} \mathrm{L}^{-1}\right)$ (Fig. 7c).

The performance of biofilms of both strains in the PBR showed significant differences $(P<0.05)$ in $\mathrm{pH}$ : the $\mathrm{pH}$ of the synthetic wastewater in PBR with $S$. vacuolatus displayed a less variation between $\mathrm{pH} 7$ and 8 . On the other hand, the $\mathrm{pH}$ in synthetic growth medium in PBR with $C$. vulgaris increased up to 10 and kept constant at this $\mathrm{pH}$ value. Biomass growth between the liquid phase of the PBR system with S. vacuolatus ACUF_053 and C. vulgaris ACUF_809 were significantly different $(P<0.05)$. Higher biomass concentrations were recorded in the synthetic wastewater in the PBR with S. vacuolatus biofilm compared to the medium in the PBR with $C$. vulgaris biofilm.

\section{Discussion}

\section{Suspended vs. attached microalgae growth}

This study showed that the microalgae strains $S$. vacuolatus ACUF_053 and C. vulgaris ACUF_809 grew both under suspension and attached conditions in the new PBR configuration. In other studies, the surface colonization by microalgae has been reported within $24 \mathrm{~h}$ in horizontal systems (Irving and Allen 2011). In this study, the algae colonization lasted $7( \pm 1)$ days. Long term ( $\geq 3$ months) stability has been demonstrated in continuous studies despite the dynamic nature of algal biofilms (Boelee et al. 2011). During the 7 days of the comparative experiments, the algae strains showed adhesion onto cotton in the PBR (Figs. 4a, 7a). This period could present an adaptation phase of the algae cells to the medium flow and the surface features of the carrier material. Suspended algal systems are designed to minimize attachment or settlement of cells onto bioreactor surfaces. In contrast, attached algal systems, as used in this study, promote cell adhesion to a surface favoured by a polymeric matrix on the cotton fabric material (Kesaano and Sims 2014). Cotton fabric not only supports excellent attachment for algal growth, but it's also durable and low cost (Johnson and Wen 2010; Gross et al. 2013).

The biomass concentration obtained in the suspended culture was $0.37 \mathrm{~g} \mathrm{~L}^{-1}$ and $0.2 \mathrm{~g} \mathrm{~L}^{-1}$, respectively, for $S$. vacuolatus ACUF_053 and C.vulgaris ACUF_809; which falls in the range of $0.1-1 \mathrm{~g} \mathrm{~L}^{-1}$ as reported by Jonson and Wen (2010). Similar biomass concentrations were reported for Chlorella sp., i.e. $0.1 \mathrm{~g} \mathrm{~L}^{-1}$ (Nayak et al. 2013) and for C. vulgaris, i.e. $0.39 \mathrm{~g} \mathrm{~L}^{-1}$ (Matos et al. 2015) grown in BBM. However, this concentration is low compared with the one obtained for S. vacuolatus ACUF_053 (2.9 $\left.\mathrm{g} \mathrm{L}^{-1}\right)$ by Gargano et al. (2016) and for Scenedesmus sp. (0.78-0.87 $\mathrm{g} \mathrm{L}^{-1}$ ) by Nayak et al. (2013).

Nutrient removal trends in the suspended cell experiments showed a singular biomass growth pattern for $S$. vacuolatus ACUF_053: low uptake percentages were observed at the beginning of the growth phase (Fig. 2), increased uptake occurred in parallel with the growth peaks and the stationary phase was characterized by a complete nutrient removal from the medium (Boelee et al. 2011; Kesaano and Sims 2014). Low nutrient removal efficiencies at the beginning of the growth phase of microalgae biofilms have been reported (de Godos et al. 2009). This behaviour was attributed to the insufficient establishment and acclimation of the algal biofilm community. In contrast, a high nutrient removal percentage, especially phosphorus, was observed during the establishment of the S. vacuolatus ACUF_053 biofilm (Fig. 4a). C. vulgaris ACUF_809 showed similar removal efficiencies in its suspended and attached growth (Fig. 5b).

Microalgae can store phosphorus within the biomass as polyphosphates that can be actively involved in the metabolism of the cell or being stored for when the external phosphate concentration becomes limiting (Powell et al. 2009). However, the difference in the $\mathrm{PO}_{4}{ }^{3-}-\mathrm{P}$ removal efficiency between suspended and attached cell conditions could be related to polymeric substances (EPS) formation. EPS are mainly composed of polysaccharides, proteins, extracellular DNA (eDNA) and lipids (Singha 2012). Previous studies reported a high EPS to biomass ratio in young algal biofilms. Hence, the authors suggested that this probably occurs due to EPS production as a survival mechanism (Barranguet et al. 2005), although EPS on the algal biofilms was not measured in this study to avoid contamination and destruction of the biofilm during the analysis. A maximum EPS production during the early stationary growth phase (about 8 days) was reported by Wolfstein and Stal (2002), which fits the period of the highest phosphorous demand by $S$. vacuolatus ACUF_053 (Fig. 2). A possible contribution of EPS to the initial process of cell attachment in young biofilms has been suggested (Romaní et al. 2008). On the other hand, microalgal EPS production and composition can vary depending on different factors, i.e. the strain, stress conditions, nutrient concentrations and community diversity (El-Sheekh et al. 2012; Matsumoto et al. 2014; Xiao and Zheng 2016).

\section{Development of S. vacuolatus ACUF_053 and C. vulgaris ACUF 809 biofilms in PBR}

Biofilm-based photobioreactors are typically designed with high surface area to volume ratios for an efficient light penetration. However, immobilized algal cultures on the reactor surfaces are vulnerable to photodamage from constant exposure to high irradiation (Muñoz et al. 2009). An irradiation range between 12 and $88 \mu \mathrm{mol} \mathrm{m} \mathrm{m}^{-2} \mathrm{~s}^{-1}$ is a limited condition for algal biofilms (Hill and Fanta 2008). In this study, the irradiation used was over this 
range $\left(90 \mu \mathrm{mol} \mathrm{m} \mathrm{m}^{-2} \mathrm{~s}^{-1}\right)$ and it was constant during the experiment. The biofilm PBR configuration tested has several advantages: (1) a lower footprint than horizontal systems, (2) medium dropping ensures a simple but constant contact of biofilm with the growth medium, (3) the thin medium layer and slow flow rate to which the algal biofilm is exposed allows a reduction in the required volume of the medium (Boelee et al. 2011; Katarzyna et al. 2015) and (4) biofilm detachment/regrowth phases allow serial growth/harvesting cycles.

Biofilm accumulation is determined by the balance of attachment, growth and detachment processes (Hunt et al. 2004; Kesaano and Sims 2014; D'Acunto et al. 2015; Mattei et al. 2018). Five phases were defined according to the observed colonization, nutrient removal and the green intensity of the cotton fabric carrier by $S$. vacuolatus ACUF_053 (Fig. 3). On the contrary, the marked distinction in time of biofilm morphology and nutrient removal by C. vulgaris ACUF_809 (Figs. 6, 7a) was not observed with the S. vacuolatus ACUF_053 biofilms. This could be due to differences in the EPS production: with a low EPS production the microalgae cells take longer to establish cell to cell interactions, which increase the biomass content (thickness) of the biofilm (Ozkan and Berberoglu 2013; Matsumoto et al. 2014). This suggests a longer biofilm maturation period that was not totally comprised during the experimental time. This could be the cause for the constant microalgae biomass concentration measured in the synthetic wastewater circulating in the PBR (Fig. 7c).

Scenedesmus vacuolatus ACUF_053 biofilm exhibited a second maturation phase at day 35 , the following days a gradual decrease of the biomass concentration in the synthetic wastewater was observed (Fig. 4c) accompanied by the re-greenering of the carrier. In general, the attachment of algal cells to the free surface of the materials is crucial and can be time consuming. Once the initial colonization occurs, attachment of additional algal cells to the existing algal biofilm layer is relatively easier (Ozkan and Berberoglu 2013; D'Acunto et al. 2015).

The steep increase in $\mathrm{pH}$ values in the synthetic wastewater observed during the $C$. vulgaris ACUF_809 biofilm formation could represent an impact on the integrity of the biofilm, which resulted in the detachment of biomass from the biofilm (Qureshi et al. 2005). Freshwater chlorophytes are capable of tolerating a wide range of $\mathrm{pH}$, due to an acquired tolerance to both acidic and alkaline $\mathrm{pH}$ as an adaptive response to widely fluctuating $\mathrm{pH}$ levels that occur commonly in many productive freshwater environments (Goldman et al. 1982). It was reported that Scenedesmus obliquus (Turp.) Kutz. and Chlorella vulgaris Beij. can grow up to $\mathrm{pH} 10.6$ although $C$. vulgaris is more adversely affected by alkaline $\mathrm{pH}$ than was $S$. obliquus (Goldman et al. 1982).
The difference observed in the $\mathrm{pH}$ behaviour for $S$. vacuolatus and $C$. vulgaris in the PBR biofilm formation can be due to the ability of some blue-green algae as well as green algae strains to alter the $\mathrm{pH}$ of the culture media (Wildman et al. 1974). As it was observed, the $\mathrm{pH}$ values of the synthetic wastewater went up to about 10 and 10.5, respectively, in S. vacuolatus ACUF_053 and C. vulgaris ACUF_809 suspended cultivations (Figs. 1b, $5 \mathrm{~b})$, respectively. However, the $\mathrm{pH}$ in the $S$. vacuolatus ACUF_053 biofilm cultivation was about 8 (Fig. 4b). This might be explained by a higher production of EPS, which can protect the cell from $\mathrm{pH}$ damage (Bethmann and Schönknecht 2009). It is known that $\mathrm{pH}$ plays an important role in both microalgal growth and flocculation. Most algae species achieve higher biomass productivity as the $\mathrm{pH}$ rise from 6 to 9 (Molina Grima et al. 2003). However, since the cell membrane and EPS of microalgae are mainly composed of polysaccharides, proteins and lipids, the components of extracellular metabolites can vary with different $\mathrm{pH}$ (Shen et al. 2014). Alternatively, the algae can excrete acids to neutralize the basic conditions to protect their microenvironment (Bethmann and Schönknecht 2009). According to Zhang et al. (2011), when the $\mathrm{pH}$ is above 9, microalgal cells may release EPS to protect themselves from the environment.

The increase in $\mathrm{pH}$ values over 8 was recorded during the maturation phase of S. vacuolatus ACUF_053 biofilms (Fig. 4b), when the higher photosynthetic activity occurred due to the high biomass concentration growing on the cotton. Algal photosynthetic activity raises the $\mathrm{pH}$ of the medium (Wei et al. 2008). Therefore, the results suggest a different EPS production between S. vacuolatus ACUF_053 and C. vulgaris ACUF_809; this should be demonstrated quantitatively to propose the application of biofilm technologies of these strains for different biotechnological processes, e.g. treatment of different types of wastewater.

During the 41 days of the experiment, different nutrient uptake rates were displayed by $S$. vacuolatus ACUF_053, which correlate with the biofilm development phases (Fig. 3). C. vulgaris ACUF_809 showed high maximum removal efficiencies, i.e. nitrate (89\%) and phosphate (91\%). Previous studies have shown that microalgal biofilm systems can achieve good nitrogen and phosphorus removal efficiencies from wastewater. Removal capacities of over $90 \%$ were measured for nitrate $\left(\mathrm{NO}_{3}{ }^{-}\right)$and over $80 \%$ for phosphate $\left(\mathrm{PO}_{4}{ }^{3-}\right)$ (Craggs et al. 1997; Shi et al. 2007; de Godos et al. 2009).

\section{Conclusions}

This study showed biofilms of S. vacuolatus ACUF_053 and C. vulgaris ACUF_809 have a high capacity for nutrient removal. Attached growth of S. vacuolatus had a 
higher phosphate removal efficiency than the suspended cultures. Complete removal of nitrate $\left(60-240 \mathrm{mg} \mathrm{L}^{-1}\right)$ and phosphate (20-40 $\left.\mathrm{mg} \mathrm{L}^{-1}\right)$ was recorded during the S. vacuolatus biofilm formation and maturation phases, and C. vulgaris ACUF_809 achieved a nutrient removal efficiency of about $90 \%$ during the semi-batch process in the PBR. It was observed that the depletion of one of the nutrients limited the removal of the other.

The biofilm PBR design using S. vacuolatus and C. vulgaris showed potential for wastewater treatment due its higher removal rates. S. vacuolatus biofilms showed two advantages for the potential application in wastewater treatment: first, the possibility of biomass harvesting at the end of the maturation phases, and second the higher nutrient removal efficiency compared with suspended cell cultures under batch conditions. The phases of the S. vacuolatus biofilm development showed differences in nutrient removal efficiency. The biofilm showed a higher demand of phosphate during the initial adhesion and formation phases, while it has a higher nitrate demand during the subsequent maturation phase.

\section{Abbreviations \\ PBR: photobioreactor; ACUF: Algae collection of University of Napoli "Federico II"; ATS: algal turf scrubber; M8A: growth medium 8A; BG 11: blue-green medium; WWTP: wastewater treatment plant; WW: wastewater; BBM: bold's basal medium; CMM: complete mineral medium; MLM: microelement limiting medium; SLM: sulphur limiting medium; NLM: nitrogen limiting medium; MSM: mineral salt medium; OD: optical density; DCW: dry cell weight; LED: light-emitting diode; APHA: american public health association.}

\section{Acknowledgements}

The authors thank Dr. Ludovico Pontoni and Elia Toscano from the University of Naples "Federico II" (Naples, Italy) for laboratory and instrument assistance.

\section{Authors' contributions}

JHMO performed the research experiments and wrote the manuscript. GP helped in the manuscript writing. AP and LF helped in the experiments and guided the author during the experiments and manuscript preparation. PNLL and GE worked actively in the development of this manuscript. All authors read and approved the final manuscript.

\section{Funding}

Financial support was provided by EU through the Erasmus Mundus Joint Doctorate Programme, Environmental Technologies for Contaminated Solids, Soils and Sediments, Grant Agreement FPA No. 2010-0009 (ETeCoS ${ }^{3}$ ).

\section{Availability of data and materials}

The datasets supporting the conclusions of this article are included in the main manuscript. The authors promise to provide any missing data on request.

\section{Ethics approval and consent to participate}

Not applicable.

\section{Consent for publication}

Not applicable.

\section{Competing interests}

The authors declare that they have no competing interests.

\section{Author details}

${ }^{1}$ Department of Civil and Mechanical Engineering, University of Cassino and Southern Lazio, Via Di Biasio, 43, 03043 Cassino, Italy. ${ }^{2}$ Department of Biology, University of Naples "Federico II", Via Cintia-Complex Monte S. Angelo, 26, 80126 Naples, Italy. ${ }^{3}$ Department of Mathematics and Applications Renato Caccioppoli, University of Naples "Federico II", Via Cintia, Monte S. Angelo, 80126 Naples, Italy. ${ }^{4}$ UNESCO-IHE Institute for Water Education, Westvest 7, 2611 AX Delft, The Netherlands. ${ }^{5}$ National University of Ireland Galway, University Road, Galway H91 TK33, Ireland. ${ }^{6}$ Department of Civil, Architectural and Environmental Engineering, University of Naples "Federico II", Via Claudio 21,80125 Naples, Italy.

Received: 10 March 2019 Accepted: 2 July 2019

Published online: 31 July 2019

\section{References}

Abdel-Raouf N, Al-Homaidan AA, Ibraheem IB (2012) Microalgae and wastewater treatment. Saudi J Biol Sci 19:257-275

APHA (2005) Standard methods for the examination of water and wastewater. Washington, D.C, APHA

Babu M (2011) Effect of algal biofilm and operational conditions on nitrogen removal in waste stabilization ponds. Doctor in Philosophy, UNESCO-IHE Institute for Water Education, Delft

Barranguet C, Veuger B, Van Beusekom SAM, Marvan P, Sinke JJ, Admiraal W (2005) Divergent composition of algal-bacterial biofilms developing under various external factors. Eur J Phycol 40:1-8

Barros Al, Gonçalves AL, Simões M (2018) Microalgal/cyanobacterial biofilm formation on selected surfaces: the effects of surface physicochemical properties and culture media composition. J Appl Phycol 31:375-387

Berner F, Heimann K, Sheehan M (2015) Microalgal biofilms for biomass production. J Appl Phycol 27:1793-1804

Bernstein HC, Kesaano M, Moll K, Smith T, Gerlach R, Carlson RP, Miller CD, Peyton BM, Cooksey KE, Gardner RD, Sims RC (2014) Direct measurement and characterization of active photosynthesis zones inside wastewater remediating and biofuel producing microalgal biofilms. Bioresour Technol 156:206-215

Bethmann B, Schönknecht G (2009) pH regulation in an acidophilic green alga - a quantitative analysis. New Phytol 183:327-339

Bhaiji T (2016) Enhancing microalgae attachment for biofilm-based photobioreactors. PhD, School of Aerospace, Transport and Manufacturing, Cranfield University, Cranfield

Blanken W, Janssen M, Cuaresma M, Libor Z, Bhaiji T, Wijffels RH (2014) Biofilm growth of Chlorella sorokiniana in a rotating biological contactor based photobioreactor. Biotechnol Bioeng 111:2436-2445

Boelee NC, Temmink H, Janssen M, Buisman CJ, Wijffels RH (2011) Nitrogen and phosphorus removal from municipal wastewater effluent using microalgal biofilms. Water Res 45:5925-5933

Carbone DA, Gargano I, Pinto G, De Natale A, Pollio A (2017) Evaluating microalgal attachment to surfaces: a first approach towards a laboratory integrated assessment. Chem Eng Trans 57:73-78

Craggs R, McAuley P, Smith V (1997) Wastewater nutrient removal by marine microalgae grown on a corrugated raceway. Water Res 31:1701-1707

D'Acunto B, Frunzo L, Klapper I, Mattei MR (2015) Modeling multispecies biofilms including new bacterial species invasion. Math Biosci 259:20-26

de Godos I, Gonzalez C, Becares E, Garcia-Encina PA, Munoz R (2009) Simultaneous nutrients and carbon removal during pretreated swine slurry degradation in a tubular biofilm photobioreactor. Appl Microbiol Biotechnol 82:187-194

El-Sheekh MM, Mohamed Khairy H, El-Shenody R (2012) Algal production of extra and intra-cellular polysaccharides as an adaptive response to the toxin crude extract of Microcystis aeruginosa. Iranian J Environ Health Sci Eng 9:10

Gao F, Yang ZH, Li C, Zeng GM, Ma DH, Zhou L (2015) A novel algal biofilm membrane photobioreactor for attached microalgae growth and nutrients removal from secondary effluent. Bioresour Technol 179:8-12

Gargano I, Olivieri G, Andreozzi R, Marotta R, Marzocchella A, Pollio A (2016) Biodiesel production in outdoor cultures of Scenedesmus vacuolatus. Chem Eng Trans 49:397-402 
Goldman JC, Azov Y, Riley CB, Dennett MR (1982) The effect of pH in intensive microalgal cultures. I. Biomass regulation. J Exp Mar Biol Ecol 57:1-13

Gross M, Henry W, Michael C, Wen Z (2013) Development of a rotating algal biofilm growth system for attached microalgae growth with in situ biomass harvest. Bioresour Technol 150:195-201

Gross M, Jarboe D, Wen Z (2015) Biofilm-based algal cultivation systems. Appl Microbiol Biotechnol 99:5781-5789

Gupta PL, Choi HJ, Lee SM (2016) Enhanced nutrient removal from municipal wastewater assisted by mixotrophic microalgal cultivation using glycerol. Environ Sci Pollut R 23:10114-10123

Han T, Lu HF, Ma SS, Zhang YH, Liu ZD, Duan N (2017) Progress in microalgae cultivation photobioreactors and applications in wastewater treatment: a review. Int J Agric Biol Eng 10:1-29

Heeg JS, Wolf M (2015) ITS2 and 18S rDNA sequence-structure phylogeny of Chlorella and allies (Chlorophyta, Trebouxiophyceae, Chlorellaceae). Plant Gene 4:20-28

Hegewald E, Bock C, Krienitz L (2013) Aphylogenetic study on Scenedesmaceae with the description of Pectinodesmus and the new genera Verrucodesmus and Chodatodesmus (Chlorophyta, Chlorophyceae). Fottea Olomouc 13:149-164

Hill RW, Fanta SE (2008) Phosphorous and light colimit growth at subsaturating irradiances. Freshwater Biol 53:215-225

Huang Y, Zheng Y, Li J, Liao Q, Fu Q, Xia A, Fu J, Sun Y (2018) Enhancing microalgae biofilm formation and growth by fabricating microgrooves onto the substrate surface. Bioresour Technol 261:36-43

Hunt SM, Werner EM, Huang B, Hamilton MA, Stewart PS (2004) Hypothesis for the role of nutrient starvation in biofilm detachment. Appl Environ Microbiol 70:7418-7425

Irving TE, Allen DG (2011) Species and material considerations in the formation and development of microalgal biofilms. Appl Microbiol Biotechnol 92:283-294

Johnson MB, Wen Z (2010) Development of an attached microalgal growth system for biofuel production. Appl Microbiol Biotechnol 85:525-534

Katarzyna L, Sai G, Singh OA (2015) Non-enclosure methods for non-suspended microalgae cultivation: literature review and research needs. RenewSust Energ Rev 42:1418-1427

Kebede-Westhead E, Pizarro C, Mulbry WW (2006) Treatment of swine manure effluent using freshwater algae: production, nutrient recovery, and elemental composition of algal biomass at four effluent loading rates. J Appl Phycol 18:41-46

Kesaano M, Sims RC (2014) Algal biofilm based technology for wastewater treatment. Algal Res 5:231-240

La Russa M (2009) Green algae selection useful for phycoremediation of olive-mill wastewaters and increase of their lipid content by genetic engineering. Ph.D., Department of Biology, University of Naples "Federico III, Napoli, Italy

Li X, Hu H, Gan K, Sun Y (2010) Effects of different nitrogen and phosphorus concentrations on the growth, nutrient uptake, and lipid accumulation of a freshwater microalga Scenedesmus sp. Bioresour Technol 101:5494-5500

Liu T, Wang J, Hu Q, Cheng P, Ji B, Liu J, Chen Y, Zhang W, Chen X, Chen L, Gao $\mathrm{L}$, Ji C, Wang H (2013) Attached cultivation technology of microalgae for efficient biomass feedstock production. Bioresour Technol 127:216-222

Mata TM, Martins AA, Caetano NS (2010) Microalgae for biodiesel production and other applications: a review. RenewSust Energ Rev 14:217-232

Matos ÂP, Brasileiro F, de Oliveira Torres RC, Ito Morioka LR, Machado Canella MH, Rotta J, da Silva T, Siegel Moecke EH, Sant'Anna ES (2015) Optimization of biomass production of Chlorella vulgaris grown in desalination concentrate. J Appl Phycol 27:1473-1483

Matsumoto T, Yamamura H, Hayakawa J, Watanabe Y, Harayama S (2014) Influence of extracellular polysaccharides (EPS) produced by two different green unicellular algae on membrane filtration in an algae-based biofuel production process. Water Sci Technol 69:1919-1925

Mattei MR, Frunzo L, D'Acunto B, Pechand Y, Pirozzi F, Esposito G (2018) Continuum and discrete approach in modeling biofilm development and structure: a review. J Math Biol 76:945-1003

Moheimani NR, Borowitzka MA, Isdepsky A, FonSing S (2013) Standard methods for measuring growth of algae and their composition. In: Borowitzka MA, Moheimani NR (eds) Algae for biofuels and Energy. Springer, Dordrecht, pp 265-284
Molina Grima E, Belarbia E-H, Acién Fernández FG, Robles Medinaa A, Chisti Y (2003) Recovery of microalgal biomass and metabolites:process options and economics. Biotechnol Adv 20:491-515

Moreno Osorio JH, Luongo V, Del Mondo A, Pinto G, Frunzo L, Lens PNL, Esposito G (2018) Nutrient removal from high strength nitrate containing industrial wastewater using Chlorella sp. strain ACUF_802. Ann Microbiol 68:899-913

Muñoz R, Kollner C, Guieysse B (2009) Biofilm photobioreactors for the treatment of industrial wastewaters. J Hazard Mater 161:29-34

Naumann T, Çebi Z, Podola B, Melkonian M (2013) Growing microalgae as aquaculture feeds on twin-layers: a novel solid-state photobioreactor. J Appl Phycol 25:1413-1420

Nayak M, Rath SS, Thirunavoukkarasu M, Panda PK, Mishra BK, Mohanty RC (2013) Maximizing biomass productivity and $\mathrm{CO}_{2}$ biofixation of microalga, Scenedesmus sp. by using sodium hydroxide. J Microbiol Biotechnol 23:1260-1268

Ozkan A, Berberoglu H (2013) Cell to substratum and cell to cell interactions of microalgae. Colloids Surf B Biointerfaces 112:302-309

Ozkan A, Kinney K, Katz L, Berberoglu H (2012) Reduction of water and energy requirement of algae cultivation using an algae biofilm photobioreactor. Bioresour Technol 114:542-548

Powell N, Shilton A, Chisti Y, Pratt S (2009) Towards a luxury uptake process via microalgae-defining the polyphosphate dynamics. Water Res 43:4207-4213

Prajapati SK, Kaushik P, Malik A, Vijay VK (2013) Phycoremediation coupled production of algal biomass, harvesting and anaerobic digestion: possibilities and challenges. Biotechnol Adv 31:1408-1425

Qureshi N, Annous BA, Ezeji TC, Karcher P, Maddox IS (2005) Biofilm reactors for industrial bioconversion processes: employing potential of enhanced reaction rates. Microb Cell Fact 4:24

Rajendran A, Hu B (2016) Mycoalgae biofilm: development of a novel platform technology using algae and fungal cultures. Biotechnol Biofuels 9:112

Romaní AM, Fund K, Artigas J, Schwartz T, Sabater S, Obst U (2008) Relevance of polymeric matrix enzymes during biofilm formation. Microb Ecol 56:427-436

Schnurr PJ, Espie GS, Allen DG (2013) Algae biofilm growth and the potential to stimulate lipid accumulation through nutrient starvation. Bioresour Technol 136:337-344

Schumacher G, Sekoulov I (2002) Polishing of secondary effluent by an algal biofilm process. Water Sci Technol 46:83-90

Shen Y, X X X, Zhao Y, Lin X (2014) Influence of algae species, substrata and culture conditions on attached microalgal culture. Bioprocess Biosyst Eng $37: 441-450$

Shen Y, Zhang H, Xu X, Lin X (2015) Biofilm formation and lipid accumulation of attached culture of Botryococcus braunii. Bioprocess Biosyst Eng 38:481-488

Shi J, Podola B, Melkonian M (2007) Removal of nitrogen and phosphorus from wastewater using microalgae immobilized on twin layers: an experimental study. J Appl Phycol 19:417-423

Silva-Aciares FR, Riquelme CE (2008) Comparisons of the growth of six diatom species between two configurations of photobioreactors. Aquacult Eng 38:26-35

Singha TK (2012) Microbial extracellular polymeric substances: production, isolation and applications. IOSR J Pharm 2:276-281

Sirmerova M, Prochazkova G, Siristova L, Kolska Z, BranyikT (2013) Adhesion of Chlorella vulgaris to solid surfaces, as mediated by physicochemical interactions. J Appl Phycol 25:1687-1695

Spolaore P, Joannis-Cassan C, Duran E, Isambert A (2006) Commercial applications of microalgae. J Biosci Bioeng 101:87-96

Tam NFY, Lau PS, Wong YS (1994) Wastewater inorganic N removal and P removal by immobilized Chlorella vulgaris. Water Sci Technol 30:369-374

Toninelli AE, Wang J, Liu M, Wu H, Liu T (2016) Scenedesmus dimorphus biofilm: photoefficiency and biomass production under intermittent lighting. Sci Rep 6:32305

Wei Q, Hu Z, Li G, Xiao B, Sun H, Tao M (2008) Removing nitrogen and phosphorus from simulated wastewater using algal biofilm technique. Front Environ Sci Eng 2:446-451

Wildman RB, Benner BL, Held DD, Schauberger CW (1974) Influence of bluegreen algae on the $\mathrm{pH}$ and buffer capacity of culture media. Proc lowa Acad Sci 81:192-196 
Wilkie AC, Mulbry WW (2002) Recovery of dairy manure nutrients by benthic freshwater algae. Bioresour Technol 84:81-91

Wolfstein K, Stal JL (2002) Production of extracellular polymeric substances (EPS) by benthic diatoms: effect of irradiance and temperature. Mar Eco Prog Ser 236:13-22

Xiao R, Zheng Y (2016) Overview of microalgal extracellular polymeric substances (EPS) and their applications. Biotechnol Adv 34:1225-1244

Yan C, Luo X, Zheng Z (2013) Effects of various LED light qualities and light intensity supply strategies on purification of slurry from anaerobic digestionprocess by chlorella vulgaris. Int Biodeterior Biodegradation 79:81-87

Young AM (2011) Zeolite-Based agae biofilm rotating photobioreactor for algae and biomass production Mster of Science, Biological Engineering. Utah State University, Utah

Zamalloa C, Boon N, Verstraete W (2013) Decentralized two-stage sewage treatment by chemical-biological flocculation combined with microalgae biofilm for nutrient immobilization in a roof installed parallel plate reactor. Bioresour Technol 130:152-160

Zhang H, Kuang Y, Zhe L, Liu C (2011) Influence on surface characteristics of microalgae cell by solution chemistry. Adv Mater Res 287-290:1938-1942

Zheng Y, Huang Y, Liao Q, Fu Q, Xia A, Zhu X (2017) Impact of the accumulation and adhesion of released oxygen during Scenedesmus obliquus photosynthesis on biofilm formation and growth. Bioresour Technol 244:198-205

\section{Publisher's Note}

Springer Nature remains neutral with regard to jurisdictional claims in published maps and institutional affiliations.

\section{Submit your manuscript to a SpringerOpen ${ }^{\circ}$ journal and benefit from:}

- Convenient online submission

- Rigorous peer review

- Open access: articles freely available online

- High visibility within the field

- Retaining the copyright to your article

Submit your next manuscript at $\boldsymbol{\nabla}$ springeropen.com 